\title{
DOGŁĘBNIE I CIEKAWIE O NOWYCH BUŁGARSKICH FEMINATYWACH
}

\author{
Petar Sotirov \\ Maria Curie-Sklodowska University in Lublin
}

\begin{abstract}
IN-DEPTH AND INTERESTING: ON NEW BULGARIAN FEMINATIVES. A review of: Sumrova, Vanina. New Feminitives in Bulgarian. Sofia: Prof. Marin Drinov - BAS, 2018, 196 pp. ISBN 978-954-322-952-9 [in Bulgarian: Сумрова, Ванина. Новите феминални названия в българския език. София: БАН - Проф. Марин Дринов, 2018].
\end{abstract}

Keywords: feminitives, terms denoting women, Bulgarian language, Vanina Sumrova

W okresie po 1989 roku neologizmy stały się jednym z wiodących tematów dla leksykologii и leksykografii bułgarskiej. Świadczy o tym fakt, że na rynku wydawniczym ostatnio pojawiły się liczne publikacje. ${ }^{1}$ Wśród nich na szczególną uwagę zasługuje książka autorstwa Vaniny Sumrowej pt. Nowe nazwy feminatywne w języku bułgarskim [Сумрова, Ванина. Новите феминални названия в българския език. София: Издателство на БАН Проф. Марин Дринов, 2018, 196 с.].

Prezentowana monografia jest wynikiem wieloletnich dociekań autorki ${ }^{2}$ i dowodzi jej doskonałego przygotowania teoretycznego i metodologicznego oraz dojrzałości naukowej. Należy podkreślić, że tekst książki, który obejmuje wstęp, sześć rozdziałów, zakończenie, bibliografię, dwa aneksy i streszczenie w języku angielskim, stanowi nie tylko przedstawienie faktów, ale również zawiera ciekawy i kompetentny komentarz autorski, który w wielu miejscach prowokuje do refleksji i stwarza warunki do dyskusji.

W części wstępnej książki (s. 7-24), gdzie oczywiście przedstawione są obiekt, cele i metodologia badawcza, znalazł się również interesujący rozdział pt. Przyczyny wzbogacenia się leksykalno-semantycznej grupy feminatywów w języku bułgarskim po roku 1989, w którym w sposób bardzo klarowny zaprezentowano autorskie pojmowanie istoty badanej problematyki. Tutaj Vanina Sumrova wyraziła swoje przekonanie, że podjęta tematyka

1 Zob. np. RNDBE 2010; Kolkovska 2012, 2013; Blagoeva 2016; Kolkovska \& Blagoeva 2016; Kostova 2018 i in.

2 Zob. niektóre z poprzednich publikacji autorki, np.: Sumrova 1999, 2011, 2017. 
przekracza granice czystego językoznawstwa i wkracza na terytorium dyscyplin takich jak socjolingwistyka, lingwistyka kognitywna czy lingwistyka kulturowa. W tym fragmencie tekstu autorka szczegółowo omówiła czynniki (językowe i pozajęzykowe), które oddziaływują na proces kreowania bułgarskiego systemu żeńskich nazw osobowych. Obok dosyć oczywistych czynników, na przykład wzmocnienia roli kobiet w życiu społecznym, na uwagę zasługują niektóre oryginalne spostrzeżenia autorki na temat przyczyn aktywnego powstawania badanych nazw. Wymieniono wśród nich na przykład: słowotwórczy potencjał języka bułgarskiego, narodowy paradygmat rodzajowy, który odgrywa rolę swoistego etalonu ${ }^{1}$, zmiany w myśleniu i w postrzeganiu świata itd.

W kolejnych rozdziałach omawianej monografii przeprowadzona jest wieloaspektowa i kompleksowa analiza materiału empirycznego, która dotyczy struktury, semantyki, funkcji i innych osobliwości badanych jednostek.

Rozdział pierwszy pt. Techniki nominacji (s. 25-65) poświęcony jest technikom nominacji, za pomocą których powstają nowe feminatywy w języku bułgarskim: słowotwórstwu, nominacji wtórnej (derywacji semantycznej) i zapożyczaniu. W centrum uwagi znalazło się tutaj słowotwórstwo, które ma największą rolę w generowaniu nowych nazw żeńskich. W związku z tym szczegółowo omówiono podstawowe mechanizmy słowotwórcze, jakimi są derywacja, kompozycja i uniwerbizacja. Autorka zauważyła, że w ramach derywacji przewagę ma sufiksacja, a na podstawie bogatego materiału ilustracyjnego wyodrębniono konkretne formanty biorące najczęściej udział w powstawaniu nowych feminatywów. Bardzo ciekawe są tutaj przykłady pojawienia się nazw żeńskich jako korelatów nazw odnoszących się semantycznie tylko do osób płci męskiej: biznesmenka < biznesmen, donżuanka < donżuan, gejka < gej, pedałka < pedat, zaistnienia nowych feminatywów od innych feminatywów, na przykład: miska < mis, bizneswomenka < buzneswomen, czy nowych nazw żeńskich motywowanych nazwami nieosobowymi, na przykład: adrenalinka < adrenalina, perhydrolka < perhydrol i in. (s. 31).

Charakterystycznie dla całego tekstu monografii jest to, że wszędzie widoczne są poglądy autorki na zaistniałe w obrębie językoznawstwa kwestie dyskusyjne. Na przykład w rozdziale pierwszym w sposób wyrazisty wybrzmiewa opinia autorki na temat kompozycji jako mechanizmu słowotwórczego. W swoich badaniach Vanina Sumrova ustaliła tylko dwa przykłady prawdziwej kompozycji, natomiast zaprezentowała liczne poświadczeń nazw z elementem typu: top-, eks-, super-, eko-, euro-, narko-, pseudo-, anti-, pres- i in.

1 Jako dowód obecności i konieczności stosowania tego typu paradygmatu rodzajowego autorka przytacza przykłady z języka dzieci lub dla dzieci, gdzie odnotowane są przypadki nazw żeńskich jako korelatów nazw męskich rodzaju: delfin - delfinka, troll - trollka, elf - elfka i in. (s. 11). 
Istotne jest, że w tym miejscu włączyła się aktywnie w obecnie prowadzoną dyskusję naukową na temat istoty sposobu nominacji za pomocą składników wymienionego typu - czy jest to derywacją, kompozycją czy stanowi zjawisko graniczne. Przyjmując termin prefiksoid dla powyższych form, autorka wyraziła stanowisko, że jednostki omawianego typu (np. topmodel, eksprezydent, supereuropejka itd.) stanowią swoistego typu composita (s. 41). W opracowaniu zostały zaprezentowane szczegółowo i na podstawie licznych przykładów również inne mechanizmy słowotwórcze, przy czym szczególną uwagę zwrócono na cechy charakterystyczne dla języka bułgarskiego.

Rozdział pierwszy zamyka prezentacja innych podstawowych technik generowania feminatywów - nominacji wtórnej i zapożyczania. Ze względu na fakt, że te dwie techniki są stosunkowo mniej stosowane poświęcone im fragmenty są krótsze. Jednak tutaj również spotykamy się z bardzo ciekawymi przykładami nazw o dodatkowych przenośnych znaczeniach, na przykład: miska, playmetka, kompanionka, prima lub z przykładami zapożyczeń z języka angielskiego, na przykład: girla, hostessa, babysitterka. W stosunku do zapożyczeń, bardzo trafna jest obserwacja, że nazwy te nie mają męskoosobowego odpowiednika.

Kolejny rozdział pt. Klasyfikacje (s. 66-8o) poświęcony jest klasyfikacji nowych żeńskich nazw osobowych. Rozdział ten ma znaczenie dla usystematyzowania wiedzy i pozwala na rozpatrywanie materiału źródłowego z różnego punktu widzenia. Większą uwagę zwrócono w nim na klasyfikację semantyczną i stylistyczną, a także na grupowanie badanych leksemów pod kątem ich zgodności z oficjalnymi normami językowymi oraz ze względu na ich chronologię. Z przeprowadzonej klasyfikacji wynikają intrygujące wnioski, na przykład dowiadujemy się, że najwięcej nowych feminatywów funkcjonuje w dziedzinach polityki i sportu, a także medycyny, sztuki, wojskowości, ekonomii i techniki. Interesujący jest także fakt, że większość badanych jednostek jest stylistycznie nacechowana, a w ramach analizy omówiono zarówno genezę obecnego stanu, jak i prognozę odnośnie tendencji rozwojowych w badanym zakresie.

Rozdział trzeci pt. Maskulinizacja rzeczowników (s. 81-124), jak wskazuje jego tytuł, posiada charakter socjokulturowy. Badane w nim jednostki poddano analizie z punktu widzenia tzw. androcentryzmu. Należy przyznać, że decyzja autorki była słuszna, ponieważ nie jest możliwe prawidłowe wyjaśnienie przyczyn pojawiania się i funkcjonowania badanych jednostek bez uwzględnienia kontekstu historyczno-społecznego i kulturowego, w tym pomijając obecny w języku androcentryzm i wyrażającą go na poziomie języka maskulinizację. Z tego powodu wydaje się logicznie, że problematyce tej poświęcony został obszerny komentarz, w ramach którego naświetlono rozmaite teoretyczne aspekty, również przedstawiono i omówiono dane z badań ankietowych na temat maskulinizacji w języku. Na początku tegoż rozdziału autorka zwróciła uwagę na pewną istotną kontrowersję 
językową, mianowicie: w języku bułgarskim istnieje możliwość utworzenia rzeczownika określającego kobietę od każdego rzeczownika męskoosobowego, jednak ta możliwość nie jest realizowana. W tym samym czasie trwale obserwowana jest tendencja maskulinizacji rzeczowników (s. 81). Dalej autorka przytoczyła 11 przyczyn istniejącego stanu rzeczy, wśród nich przyczyny zarówno o charakterze stricte językowym, jak i pozajęzykowym, wśród nich: przeniesienie obcych modeli językowych, relewantność komunikatywna nazwy, ograniczenia o charakterze semantycznym, konserwatyzm i nawyk językowy, prestiż referenta oraz przyczyny o charakterze fonetycznym, słowotwórczym, formalnym i stylistycznym. Niezwykle ciekawa w tym rozdziale jest informacja o opinii samych kobiet na temat samookreślenia się. Okazuje się, że dane te świadczą o preferowaniu przez kobiety nazw męskoosobowych jako bardziej prestiżowych (s. 102). Z całą pewnością inne kwestie w tejże części książki również zwrócą uwagę czytelnika, na przykład kwestia trudności i dyskomfortu językowego, które powoduje maskulinizacja, kwestia nastawienia społeczeństwa wobec maskulinizacji oraz kwestia równości płci na tle tego zjawiska.

Rozdział czwarty pt. Osobliwości neofeminatywów (s. 125-136) traktuje o niektórych cechach o charakterze paradygmatycznym, np. o synonimii, homonimii, antonimii i paronimii, a także o innych osobliwościach gramatycznych i semantycznych. W kolejnym rozdziale, pt. Nowe feminatywy w aspekcie lingwokulturologicznym (s. 125-136), omawiane jednostki pokazano jako odzwierciedlenie nowej roli kobiety we współczesnym społeczeństwie oraz jako językowy wyznacznik społecznego stereotypu kobiety. Autorka przedstawiła tutaj, z jednej strony, najbardziej charakterystyczne cechy zachowań współczesnej kobiety, z drugiej strony, pokazała stosunek nosicieli języka wobec tych samych zachowań. W związku z tym jako fakt naturalny, według autorki, należy traktować dużą ilość nowych nazw osobowych określających kobiety za pomocą (pseudo) sufiksów typu -manka i -choliczka, oraz występowanie wielu nazw związanych z seksualnością, wyglądem, cechami osobowości i in.

Krótki, ale niezbędny okazał się również ostatni, szósty rozdział pt. Aspekty leksykograficznej reprezentacji feminatywów (s. 144-148). Zwrócono tutaj uwagę na niektóre trudności, które sprawiają badane jednostki w procesie opracowywania słowników, na przykład przy określeniu ich cech stylistycznych. Mając na uwadze fakt, że autorka jest pracownikiem Sekcji Leksykologii i Leksykografii Instytutu Języka Bułgarskiego Bułgarskiej Akademii Nauk i sama uczestniczy w przygotowywaniu wielu opracowań leksykograficznych, zaproponowana w tymże rozdziale analiza bez wątpienia jest niezwykle pogłębiona i kompletna, a podaną informację z pełnym przekonaniem możemy uznać za całkowicie wiarygodną.

Tekst książki zamyka część podsumowująca (s. 149-152), w której w sposób zwarty jeszcze raz zaprezentowano najważniejsze obserwacje oraz wynikające z nich wnioski. 
Autorka odważyła się również na sformułowanie prognozy dotyczącej przyszłości badanych jednostek i w jej ramach wyraziła opinię, że będą one rozszerzać swój udział w komunikacji społecznej. Podstawą tej prognozy jest fakt, że nowe feminatywy, według autorki, zapełniają pewne niezajęte komórki jednego z produktywnych modeli słowotwórczych języka bułgarskiego (s. 152). Nie ulega wątpliwości, że prognoza ta, jak i cały tekst proponowanej czytelnikowi książki, sprowokuje zarówno specjalistów, jak i szerokie grono czytelników do własnych refleksji i samodzielnej oceny omawianej tutaj problematyki.

\section{REFERENCES}

Blagoeva 2016: Blagoeva, Diana. "Derivational Innovations in Bulgarian and Polish (Neologisms Formed by Blending).” In Nedkova, E. \& Pometkova, Y., eds. The Bulgarian Language and Us: 86-96. Ruse: Angel Kanchev University Press, 2016. [In Bulgarian: Благоева, Диана. „Словообразувателни иновации в българския и полския език (неологизми, образувани чрез блендинг).“ В: Недкова, Е. \& Пометкова, Я., съст. Българският език и ние. Сборник статии в чест на 65 - годишнината на доц. д-р Руси Русев: 86-96. Русе: УИ Ангел Кънчев, 2016.]

Kolkovska 2012: Kolkovska, Siya. "New Methaphorical Meanings of Nouns in the Bulgarian Language.” Balgarski ezik, no 59 (4 / 2012): 17-28. [In Bulgarian: Колковска, Сия. „Нови метафорични и метонимични значения в българския език, възникнали при съществителните имена." Български език, nо 59 (4 / 2012): 17-28.]

Kolkovska 2013: Kolkovska, Siya. "New Methaphorical Meanings of Adjectives and Verbs in the Bulgarian Language." In Blagoeva, D. \& Kolkovska, S. \& Lishkova, M., eds. Problems of Neology in the Slavic Languages: 185-207. Sofia: BAS, 2013. [In Bulgarian: Колковска, Сия. „Нови метафорични значения в българския език, възникнали при прилагателни имена и глаголи.“ В: Благоева, Д. \& Колковска, С. \& Лишкова, М., съст. Проблеми на неологията в славянските езици: 185-207. София: БАН - Проф. Марин Дринов, 2013.]

Kolkovska \& Blagoeva 2016: Kolkovska, Siya \& Blagoeva, Diana. "Variability of New Lexis in Bulgarian and Polish." Reports of the Institute of Bulgarian Language, no 29 (2016): 167-195. [Колковска, Сия \& Благоева, Диана. „Вариантност при новата лексика в българския и полския език.“ Известия на Института за български език „Проф. Л. Андрейчин“, nо 29 (2016): 167-195.]

Kostova 2018: Kostova, Nadezhda. Verbal Neologisms in the Bulgarian Language. Sofia: Avangard Prima, 2018. [In Bulgarian: Костова, Надежда. Глаголните неологизми в българския език. София: Авангард Прима, 2018.]

RNDBE 2010: Pernishka, Emiliya \& Blagoeva, Diana \& Kolkovska, Siya. Dictionary of New Words in Bulgarian. Sofia: Nauka i izkustvo, 2010. [In Bulgarian: Пернишка, Емилия \& Благоева, Диана $\&$ Колковска, Сия. Речник на новите думи в българския език. София: Наука и изкуство, 2016.]

Sumrova 1999: Sumrova, Vanina. "Dynamics of Feminine Nouns for Persons in the Modern Bulgarian Standard Language.” In Problems of Sociolinguistics. Vol. 6. Language and modernity: 95-99. Sofia: INSOLISO, 1999. [In Bulgarian: Сумрова, Ванина. „Динамика на съществителни 
имена от женски род за лица в съвременния български книжовен език.“ В: Проблеми на социолингвистиката. Т. 6. Езикът и съвременността: 95-99. София: Международно социолингвистическо дружество, 1999.]

Sumrova 2011: Sumrova, Vanina. "Dynamics in Naming Women in the Modern Bulgarian Standard Language during the Last Decade of the XX Century." In Sumrova, V. \& Bozhlilova, M. \& Kolkovska, S. \& Kostova, N. Lexicology Studies: 99-17o. Sofia: BAS, 2011. [In Bulgarian: Сумрова, Ванина. „Динамика при назоваването на лица жени в съвременния български книжовен език през последното десетилетие на XX век.“ В: Сумрова, В. \& Божилова, М. \& Колковска, С. \& Костова, Н. Студии по лексикология: 99-170. София: БАН, 2011.]

Sumrova 2017: Sumrova, Vanina. "On the Bulgarian Lexicographic Interpretation of the Feminatives." In Niseva, B. \& Skwarska, K. \& Blazek, D., eds. Modern Slavic Lexicography: 159-17o. Prague: Slavic Institute of the CAS, 2017. [In Bulgarian: Сумрова, Ванина. „За българската лексикографска интерпретация на феминативите.“ B: Niševa, B. \& Skwarska, K. \& Blažek, D., eds. Moderní slovanská lexikografie: 159-17o. Praha: Slovanský ústav AV ČR, 2017.] 